\title{
Body fat measurement among Singaporean Chinese, Malays and Indians: a comparative study using a four-compartment model and different two- compartment models
}

\author{
Mabel Deurenberg-Yap ${ }^{1 *}$, Gordon Schmidt ${ }^{2}$, Wija A. van Staveren ${ }^{3}$, Joseph G. A. J. Hautvast ${ }^{3}$ and \\ Paul Deurenberg ${ }^{3} \dagger$ \\ ${ }^{1}$ Department of Nutrition, Ministry of Health, Singapore \\ ${ }^{2}$ School of Physical Education, Nanyang Technological University, Singapore \\ ${ }^{3}$ Department of Human Nutrition and Epidemiology, Wageningen University, The Netherlands
}

(Received 24 May 2000 - Revised 21 August 2000 - Accepted 18 October 2000)

\begin{abstract}
This cross-sectional study compared body fat percentage (BF\%) obtained from a fourcompartment (4C) model with $\mathrm{BF} \%$ from hydrometry (using ${ }^{2} \mathrm{H}_{2} \mathrm{O}$ ), dual-energy X-ray absorptiometry (DXA) and densitometry among the three main ethnic groups (Chinese, Malays and Indians) in Singapore, and determined the suitability of two-compartment (2C) models as surrogate methods for assessing BF\% among different ethnic groups. A total of 291 subjects (108 Chinese, seventy-six Malays, 107 Indians) were selected to ensure an adequate representation of age range (18-75 years) and BMI range $\left(16-40 \mathrm{~kg} / \mathrm{m}^{2}\right)$ of the general adult population, with almost equal numbers from each gender group. Body weight was measured, together with body height, total body water by ${ }^{2} \mathrm{H}_{2} \mathrm{O}$ dilution, densitometry with Bodpod ${ }^{\circledR}$ and bone mineral content with Hologic ${ }^{\circledR}$ QDR-4500. BF\% measurements with a $4 \mathrm{C}$ model for the subgroups were: Chinese females 33.5 (SD 7.5), Chinese males 24.4 (SD 6.1), Malay females 37.8 (SD 6.3), Malay males 26.0 (SD 7.6), Indian females $38 \cdot 2$ (SD 7·0), Indian males $28 \cdot 1$ (SD 5.5). Differences between $\mathrm{BF} \%$ measured by the $4 \mathrm{C}$ and $2 \mathrm{C}$ models (hydrometry, DXA and densitometry) were found, with underestimation of $\mathrm{BF} \%$ in all the ethnic-gender groups by DXA of $2 \cdot 1-4 \cdot 2 \mathrm{BF} \%$ and by densitometry of $0 \cdot 5-3 \cdot 2 \mathrm{BF} \%$ ). On a group level, the differences in $\mathrm{BF} \%$ between the $4 \mathrm{C}$ model and ${ }^{2} \mathrm{H}_{2} \mathrm{O}$ were the lowest $(0 \cdot 0-1.4 \mathrm{BF} \%$ in the different groups), while differences between the $4 \mathrm{C}$ model and DXA were the highest. Differences between the $4 \mathrm{C}$ model and ${ }^{2} \mathrm{H}_{2} \mathrm{O}$ and between the 4C model and DXA were positively correlated with the 4C model, water fraction $\left(f_{\text {water }}\right)$ of fat-free mass (FFM) and the mineral fraction $\left(f_{\text {mineral }}\right)$ of FFM, and negatively correlated with density of the FFM ( $\left.\mathrm{D}_{\mathrm{FFM}}\right)$, while the difference between $4 \mathrm{C}$ model and densitometry correlated with these variables negatively and positively respectively (i.e. the correlations were opposite). The largest contributors to the observed differences were $f_{\text {water }}$ and $\mathrm{D}_{\mathrm{FFM}}$. When validated against the reference $4 \mathrm{C}$ model, $2 \mathrm{C}$ models were found to be unsuitable for accurate measurements of $\mathrm{BF} \%$ at the individual level, owing to the high errors and violation of assumptions of constant hydration of FFM and $\mathrm{D}_{\mathrm{FFM}}$ among the ethnic groups. On a group level, the best $2 \mathrm{C}$ model for measuring BF\% among Singaporeans was found to be ${ }^{2} \mathrm{H}_{2} \mathrm{O}$.
\end{abstract}

Fat-free mass: Body fat percentage: Ethnicity: Four-compartment model

Body composition has been studied using different methodologies, each with its own advantages and limitations (Lukaski, 1987; Deurenberg, 1992; Jebb \& Elia, 1993). Historically, chemical two-compartment (2C) models based on information from carcass analyses have been used as reference methods, against which other in vivo methods have generally been compared. Models have been developed to assess body composition, and one of the oldest models in body composition research is the $2 \mathrm{C}$ model of Siri (1961), in which the body is divided into two

\footnotetext{
Abbreviations: $\mathrm{BF} \%$, body fat percentage; $\mathrm{BMC}$, bone mineral content; $2 \mathrm{C}$, two-compartment; $4 \mathrm{C}$, four-compartment; $\mathrm{D}_{\mathrm{b}}$, total body density; DXA, dual-energy X-ray absorptiometry; FFM, fat-free mass; FM, fat mass; $f_{\text {mineral }}$, mineral fraction of fat-free mass; $f_{\text {protein }}$, protein fraction of fat-free mass; $f_{\text {water, }}$ water fraction of fat-free mass; TBW, total body water.

* Corresponding author: Dr Mabel Deurenberg-Yap, fax + 65 4383605, email Mabel_Yap@moh.gov.sg

$\dagger$ Nutrition Consultant, Singapore.
} 
clearly defined compartments, the fat mass (FM) and the fat free mass (FFM). The determination of body fat percentage (BF\%) using whole-body densitometry is based on this model. The assumptions of densitometry are that the densities of the FM and the FFM are constant at 0.9 and $1.1 \mathrm{~kg} / \mathrm{l}$ respectively. Total body density $\left(\mathrm{D}_{\mathrm{b}}\right)$ is determined by dividing the mass of the body in air by the volume of the body. The latter can be determined by underwater weighing or by air displacement, and BF\% can be calculated using Siri's (1961) formula. In the last decade this assumption of a constant density of FFM has been challenged frequently by researchers, who questioned its validity among different gender, age and ethnic groups and also at different levels of body fatness (Baumgartner et al. 1991; Bergsma-Kadijk et al. 1996; Visser et al. 1997).

Another methodology based on a $2 \mathrm{C}$ model is the determination of $\mathrm{BF} \%$ using ${ }^{2} \mathrm{H}_{2} \mathrm{O}$ dilution (hydrometry; Forbes, 1987). This method assumes a constant hydration of the FFM (Pace \& Rathbun, 1945). It is known that hydration of FFM varies with age (Wang et al. 1999a,b), but it is uncertain whether differences in the hydration of the FFM exist among ethnic groups. The assumption of a constant hydration of the FFM is also adopted by dualenergy X-ray absorptiometry (DXA; Roubenoff et al. 1993). Variations in the hydration of FFM can also result in changes in its density, and thus BF\% estimation from densitometry. It is obvious that the use of uniform density values or hydration factors when comparing body composition data of different (ethnic) groups may result in biased conclusions (Visser et al. 1997; Gurrici et al. 1998). For example, when the actual hydration of FFM is higher than the assumed value, there would be an underestimation of $\mathrm{BF} \%$ using hydrometry and an overestimation of $\mathrm{BF} \%$ using densitometry.

In recent years many studies have been performed to compare body composition between different ethnic groups (Jiang et al. 1991; Ortiz et al. 1992; Wang et al. 1994, 1996; Gallagher et al. 1996; Aloia et al. 1997; Gurrici et al. 1998; van Loan 1998; Deurenberg-Yap et al. 2000). The results of some of these studies may have been biased by violations of assumptions in the body composition techniques used.

With the advent of chemical- and isotope-based methods, it has become possible to subdivide the FFM into its components (water, mineral and protein), and to determine these components with a high level of accuracy (Heymsfield et al. 1997; Brodie et al. 1998). The use of such multiple-compartment models circumvents the use of nonvalidated assumptions in $2 \mathrm{C}$ models, and enables reliable comparisons to be made between groups where violation of assumptions might be present.

While the use of multiple-compartment models increases the accuracy of body composition measurements and is an important reference method, these models are more costly and require more time and facilities which may not be widely available.

In 1998 a body-composition study was conducted in Singapore as part of the National Health Survey. The study aimed to compare the BF\% measured using a chemical four-compartment (4C) model and that obtained from three commonly used 2C models (hydrometry, DXA and densitometry) among the three main ethnic groups (Chinese, Malays and Indians) in Singapore. The other objectives were to examine the validity of assumptions used in the $2 \mathrm{C}$ models, and to determine the suitability of $2 \mathrm{C}$ models as surrogate methods to measure $\mathrm{BF} \%$ among these ethnic groups.

\section{Subjects and methods}

Participants (300) in the 1998 National Health Survey (Ministry of Health, 1999) were invited to participate in a body-composition study. The subjects were selected in order to cover a wide range of age and (BMI), and to ensure that the three main ethnic groups (Chinese, Malays, Indians) were well represented within each gender group. Based on power calculation, to detect a $2 \%$ point difference in $\mathrm{BF} \%$ between $4 \mathrm{C}$ and other $2 \mathrm{C}$ models, twenty-five subjects would be sufficient for each subgroup (ethnic and gender).

In total 108 Chinese, seventy-six Malays and 107 Indians (total $n$ 291) were measured. Their ages ranged from 18 to 75 years and their BMI from 16 to $40 \mathrm{~kg} / \mathrm{m}^{2}$. Table 1 gives some characteristics of the subjects. All measurements were performed at the study site situated at the laboratory of the School of Physical Education, Nanyang Technological University, Singapore. Subjects were in the fasting state for at least $6 \mathrm{~h}$ and voided before the measurements were taken. All anthropometric measurements were performed by trained observers.

The Singapore National Medical Research Council approved the study protocol and all subjects gave their written informed consent before the measurements were taken.

Body weight was measured to the nearest $0.1 \mathrm{~kg}$ in light indoor clothing without shoes, using a digital scale. A correction of $0.5 \mathrm{~kg}$ was made for the weight of the clothes. Body height was measured without shoes with Frankfurt plane horizontal (Gordon et al. 1988), to the nearest $0 \cdot 1 \mathrm{~cm}$ using a wall-mounted stadiometer. The BMI was calculated.

Total body water (TBW) was determined using ${ }^{2} \mathrm{H}_{2} \mathrm{O}$ dilution. The subject drank a precisely weighed amount of ${ }^{2} \mathrm{H}_{2} \mathrm{O}$ (amount given varied between 10 and $11 \mathrm{~g}$ ). At $3 \mathrm{~h}$ after dosing, a $10 \mathrm{ml}$ venous blood sample was taken and plasma was separated and stored at $-20^{\circ} \mathrm{C}$ until analyses were performed. Plasma was sublimated and the sublimate was analysed for ${ }^{2} \mathrm{H}$ concentration using i.r. spectroscopy (Lukaski \& Johnson, 1985). From the given dose and the ${ }^{2} \mathrm{H}$ concentration in the sublimate, TBW was calculated, assuming a $5 \%{ }^{2} \mathrm{H}$ exchange with non-aqueous compartments in the body (Forbes, 1987). The within-individual CV of this methodology to measure TBW was found to be $1.5 \%$ by the authors (M Deurenberg-Yap, G Schmidt, WA van Staveren, JGAJ Hautvast and P Deurenberg, unpublished results). The CV is increased by about $0.5 \%$ when hydrometry is used to estimate FFM, owing the hydration factor of 0.735 used (Schoeller, 1996). BF\% was then calculated using the following equations:

$$
\begin{gathered}
\mathrm{FFM}=\mathrm{TBW} / 0 \cdot 735, \\
\mathrm{BF} \%=(\mathrm{BW}-\mathrm{FFM}) \times 100 / \mathrm{BW},
\end{gathered}
$$

where BW is body weight. 
Table 1. Characteristics of Singaporean study subjects (Mean values and standard deviations)

\begin{tabular}{|c|c|c|c|c|c|c|c|c|}
\hline & \multicolumn{2}{|c|}{ Chinese } & \multicolumn{2}{|c|}{ Malays } & \multicolumn{2}{|c|}{ Indians } & \multicolumn{2}{|c|}{ Total } \\
\hline & Mean & SD & Mean & SD & Mean & SD & Mean & SD \\
\hline \multicolumn{9}{|l|}{ Females } \\
\hline$n$ & \multicolumn{2}{|c|}{61} & \multicolumn{2}{|c|}{33} & \multicolumn{2}{|c|}{53} & \multicolumn{2}{|c|}{147} \\
\hline Age (years) & $36 \cdot 5$ & $12 \cdot 9$ & $35 \cdot 6$ & $13 \cdot 9$ & $36 \cdot 3$ & $9 \cdot 6$ & $36 \cdot 2$ & $12 \cdot 0$ \\
\hline Body weight (kg) & $54 \cdot 9^{\mathrm{a}}$ & $11 \cdot 1$ & $58 \cdot 1$ & 11.5 & $61 \cdot 1^{\mathrm{b}}$ & $14 \cdot 1$ & $57 \cdot 8$ & $12 \cdot 6$ \\
\hline Body height (m) & $1.58^{\mathrm{a}}$ & 0.06 & $1.54^{b}$ & 0.06 & 1.57 & 0.06 & 1.57 & 0.06 \\
\hline BMI $\left(\mathrm{kg} / \mathrm{m}^{2}\right)$ & $22 \cdot 1^{\mathrm{a}}$ & $4 \cdot 8$ & 24.5 & 4.9 & $24.9^{\mathrm{b}}$ & $5 \cdot 3$ & $23 \cdot 6$ & $5 \cdot 2$ \\
\hline Body density (kg/l) & $1.0309^{a}$ & 0.0185 & $1.0190^{\mathrm{b}}$ & 0.0160 & $1.0199^{b}$ & 0.0182 & 1.0243 & 0.0186 \\
\hline TBW $(\mathrm{kg})$ & $26 \cdot 0$ & $3 \cdot 4$ & $26 \cdot 3$ & 4.0 & $27 \cdot 0$ & $5 \cdot 1$ & $26 \cdot 4$ & $4 \cdot 2$ \\
\hline BMC $(g)$ & 2281 & 315 & 2223 & 272 & 2309 & 319 & 2278 & 307 \\
\hline $\mathrm{BF} \% 4 \mathrm{C}$ & $33.5^{\mathrm{a}}$ & 7.5 & $37 \cdot 8^{b}$ & $6 \cdot 3$ & $38 \cdot 2^{b}$ & $7 \cdot 0$ & 36.2 & 7.4 \\
\hline Males & & & & & & & & \\
\hline$n$ & \multicolumn{2}{|c|}{47} & \multicolumn{2}{|c|}{43} & \multicolumn{2}{|c|}{54} & \multicolumn{2}{|c|}{144} \\
\hline Age (years) & $40 \cdot 7$ & $13 \cdot 6$ & 41.4 & $12 \cdot 3$ & $43 \cdot 4$ & $12 \cdot 9$ & 41.9 & $12 \cdot 9$ \\
\hline Body weight (kg) & $65 \cdot 0$ & $10 \cdot 8$ & $69 \cdot 0$ & $12 \cdot 4$ & $69 \cdot 8$ & 11.9 & $68 \cdot 0$ & 11.8 \\
\hline Body height (m) & 1.69 & 0.05 & $1 \cdot 66^{\mathrm{a}}$ & 0.06 & $1 \cdot 70^{\mathrm{b}}$ & 0.07 & 1.68 & 0.06 \\
\hline BMI $\left(\mathrm{kg} / \mathrm{m}^{2}\right)$ & $22 \cdot 8^{\mathrm{a}}$ & 3.5 & $25 \cdot 0^{\mathrm{b}}$ & $3 \cdot 8$ & $24 \cdot 3$ & $3 \cdot 7$ & $24 \cdot 0$ & $3 \cdot 7$ \\
\hline Body density (kg/l) & 1.0448 & 0.0148 & 1.0431 & 0.0198 & 1.0410 & 0.0155 & 1.0428 & 0.0167 \\
\hline TBW $(\mathrm{kg})$ & $36 \cdot 0$ & 4.4 & $37 \cdot 1$ & 4.6 & $36 \cdot 0$ & $5 \cdot 2$ & $36 \cdot 3$ & 4.8 \\
\hline $\mathrm{BMC}(\mathrm{g})$ & 2709 & 379 & 2896 & 371 & 2844 & 419 & 2816 & 397 \\
\hline $\mathrm{BF} \%$ 4C & $24 \cdot 4^{\mathrm{a}}$ & $6 \cdot 1$ & $26 \cdot 0$ & 7.6 & $28 \cdot 1^{b}$ & 5.5 & $26 \cdot 2$ & 6.5 \\
\hline
\end{tabular}

${ }^{\mathrm{a}, \mathrm{b}}$ Mean values within rows with unlike superscript letters were significantly different $(P<0.05)$; TBW, total body water; BMC, bone mineral content; $\mathrm{BF} \% 4 \mathrm{C}$, percentage body fat measured by the four-compartment model.

Body density was determined using air plethysmography (Bodpod $^{\circledR}$, Body Composition System; Life Measurements Instruments, Concord, CA, USA) according to the instructions of the manufacturer. The method is described in detail by Dempster \& Aitkens (1995), who also reported a mean test-retest CV of $1.7 \%$ for body fat measurements. BF\% was calculated using Siri's (1961) formula:

$$
\mathrm{BF} \%=495 / \mathrm{D}_{\mathrm{b}}-450 \text {. }
$$

Bone mineral content (BMC) was measured using a Hologic ${ }^{\circledR}$ DXA whole-body X-ray densitometer (QDR4500; Hologic ${ }^{\circledR}$ Waltham, MA, USA; software version V8.23a:5). As Hologic ${ }^{\circledR}$ measurements generally result in systematically lower BMC measurements compared with Lunar ${ }^{\circledR}$ measurements (Lunar Radiation Corps, Madison, WI, USA; Tothill et al. 1994), BMC data were corrected to Lunar ${ }^{\circledR}$ values. This was found to be necessary as the Lunar $^{\circledR}$ machine was used for development of the equation of the 4C model of Baumgartner et al. (1991). A correction factor based on phantom measurements (Lunar aluminium 'spine' phantom) using a Lunar DPXL absorptiometer (software version 1.35) was determined. The established correction factor of 1.167 for the phantom was confirmed by three sets of measurements performed on two subjects over a period of 1 year. For each set these two subjects were measured twice within 1 week with both systems. The $\mathrm{CV}$ of BMC measurement by DXA is $1.5 \%$, while that for $\mathrm{BF} \%$ measurement is 3.8-6.9 \%, depending on the level of body fat (Lohman, 1996). Total body mineral was calculated as $1.235 \times \mathrm{BMC}$ (Baumgartner et al. 1991; Wang et al. 1998).

$\mathrm{BF} \%$ was calculated using the $4 \mathrm{C}$ model (including FM, TBW, total body mineral and a remaining compartment, consisting of protein and carbohydrate) as described by Baumgartner et al. (1991):

$$
\mathrm{BF} \%=205 \times\left(1.34 / \mathrm{D}_{\mathrm{b}}-0.35 \times \mathrm{A}+0.56 \times \mathrm{M}-1\right),
$$

where $\mathrm{A}$ is water fraction of body weight and $\mathrm{M}$ is mineral fraction of body weight.

FFM (kg) was calculated as body weight minus FM. The water fraction of the FFM $\left(f_{\text {water }}\right)$ was calculated as TBW/ FFM, the mineral fraction $\left(f_{\text {mineral }}\right)$ as M/FFM and the protein fraction $\left(f_{\text {protein }}\right)$ as $1-f_{\text {water }}-f_{\text {mineral }}$. As $f_{\text {protein }}$ is a derived value, the difference between $f_{\text {protein }}$ and the assumed value of 0.196 needs to be interpreted by taking into account the problem of correlation of $f_{\text {protein }}$ with $f_{\text {water }}$ and $f_{\text {mineral }}$. The density $(\mathrm{kg} / \mathrm{l})$ of the FFM was calculated as:

$$
\mathrm{D}_{\mathrm{FFM}}=1 /\left(f_{\text {water }} / 0.993+f_{\text {mineral }} / 3.038+f_{\text {protein }} / 1 \cdot 340\right),
$$

where 0.993 is the density of water, 3.038 the density of minerals and 1.340 the density of protein at $37^{\circ} \mathrm{C}$ (Deurenberg et al. 1989a).

Data were analysed using the SPSS version 8.01 for Windows program (SPSS, Chicago, IL, USA). Correlations are Pearson's correlation coefficients, or partial correlation with correction for possible confounders. Differences in variables within groups were tested with the paired $t$ test. One sample $t$ test was used to test the composition and density of the FFM from assumed values. Differences between the ethnic groups were tested using ANOVA analyses of covariance with Bonferroni post hoc tests for multiple comparisons. Bland \& Altman (1986) procedures were used for testing agreement between methods. The level of significance was set at $P<0.05$. Values are presented as means and standard deviations, unless otherwise stated.

\section{Results}

Table 1 gives the characteristics of the study subjects. Overall the men were slightly older than the women. As expected, the men were taller and heavier than the women. 
Table 2. Composition of fat-free mass (FFM) by gender and ethnic group for Singaporean Chinese, Malay and Indian participants in the bodycomposition study $\dagger$

(Mean values and standard deviations)

\begin{tabular}{|c|c|c|c|c|c|c|c|c|}
\hline & \multicolumn{2}{|c|}{ Chinese } & \multicolumn{2}{|c|}{ Malays } & \multicolumn{2}{|c|}{ Indians } & \multicolumn{2}{|c|}{ Total } \\
\hline & Mean & SD & Mean & SD & Mean & SD & Mean & SD \\
\hline \multicolumn{9}{|l|}{ Females } \\
\hline Water fraction & $0.725^{\star}$ & 0.026 & 0.737 & 0.028 & $0.727^{\star}$ & 0.026 & $0.728^{*}$ & 0.026 \\
\hline Mineral fraction & $0.079^{*}$ & 0.010 & $0.078^{*}$ & 0.008 & $0.078^{*}$ & 0.009 & $0.078^{*}$ & 0.009 \\
\hline Protein fraction & 0.196 & 0.031 & $0.186^{*}$ & 0.028 & 0.195 & 0.027 & 0.193 & 0.029 \\
\hline Density of FFM (kg/l) & $1 \cdot 1082^{*}$ & 0.0073 & $1 \cdot 1038^{*}$ & 0.0098 & $1 \cdot 1070^{*}$ & 0.0098 & $1 \cdot 1068^{*}$ & 0.0090 \\
\hline \multicolumn{9}{|l|}{ Males } \\
\hline Water fraction & $0.738^{\mathrm{a}}$ & 0.019 & $0.735^{\mathrm{a}}$ & 0.026 & $0.721^{b *}$ & 0.026 & 0.731 & 0.025 \\
\hline Mineral fraction & 0.069 & 0.005 & 0.071 & 0.008 & 0.071 & 0.008 & $0.070^{*}$ & 0.007 \\
\hline Protein fraction & $0.193^{\mathrm{a}}$ & 0.020 & $0.193^{\mathrm{a}}$ & 0.026 & $0.208^{\mathrm{b} *}$ & 0.029 & 0.199 & 0.026 \\
\hline Density of FFM $(\mathrm{kg} / \mathrm{l})$ & $1.0987^{\mathrm{a}}$ & 0.0066 & $1 \cdot 1011$ & 0.0100 & $1 \cdot 1052^{b *}$ & 0.0086 & $1 \cdot 1019^{*}$ & 0.0088 \\
\hline
\end{tabular}

a,b Mean values within rows with unlike superscript letters were significantly different (ANOVA, Bonferroni testing; $P<0.05$ ).

Mean values were significantly different from assumed values (density of FFM 1.100 , water fraction 0.735 , mineral fraction 0.069 , protein fraction 0.196 ): ${ }^{\star} P<0.05$

† For details of subjects and procedures, see Table 1 and p. 492.

There was no age difference among the ethnic groups for both men and women. Among the women, Chinese women were the lightest and tallest with lowest BMI, highest $\mathrm{D}_{\mathrm{b}}$ and lowest $\mathrm{BF} \%$. No significant difference was noted for TBW and BMC between the ethnic groups. For the men, Indians were the tallest, and had the highest BF\%. Malay men were the shortest and had the highest BMI. Chinese men had the lowest BMI and BF\%. There were no significant differences in weight, TBW, BMC and $\mathrm{D}_{\mathrm{b}}$ among men of different ethnic origins.

The composition of the FFM (calculated using the 4C model) by gender and ethnic group is presented in Table 2 . No significant difference was detected for the density of FFM, $f_{\text {water }}, f_{\text {mineral }}$ and $f_{\text {protein }}$ between the women of different ethnic groups. For men, the Chinese had the lowest density of FFM and highest $f_{\text {water }}$, while Indians had the highest $f_{\text {protein }}$. When tested against the assumed density of FFM of 1.100 (Siri, 1961), women of all three ethnic groups and Indian men had significantly higher density of FFM $(P<0 \cdot 05)$. Chinese women, Indian women and Indian men also had significantly lower $(P<0.05) f_{\text {water }}$ than the assumed 0.735 (Wang et al. 1999b). All women had significantly higher $(P<0.05) \quad f_{\text {mineral }}$ than the assumed 0.069, while Malay women and Indian men had significantly different $(P<0.05) f_{\text {protein }}$ compared with the assumed $0 \cdot 196$. There was no difference in the composition of FFM between the different age-groups in the present study (data not shown).

The differences in $\mathrm{BF} \%$ between the $4 \mathrm{C}$ model and various $2 \mathrm{C}$ models for the three ethnic groups are shown in Table 3. DXA and densitometry both underestimated BF\% in all groups, while there was a slight overestimation of BF\% with hydrometry among Chinese and Indian women, and Indian men. Generally, for both men and women in all ethnic groups, the difference in $\mathrm{BF} \%$ between the $4 \mathrm{C}$ model and ${ }^{2} \mathrm{H}_{2} \mathrm{O}$ was smallest, ranging from 0.1 (SD 2.5) $\%$ in Malay women to -1.4 (SD 2.7) \% in Indian men. On the other hand, the difference in $\mathrm{BF} \%$ between the $4 \mathrm{C}$ model and DXA was the greatest (from 2.1 (SD 2.6) \% in Chinese women to 4.2 (SD 2.4) \% in Chinese men). For women the differences in BF\% between the 4C model and all the other 2C models among ethnic groups were not significant.
Among men, the difference in $\mathrm{BF} \%$ between the $4 \mathrm{C}$ model and ${ }^{2} \mathrm{H}_{2} \mathrm{O}$ was significantly higher for Indian men compared with the other two groups $(P<0.05)$, with hydrometry overestimating $\mathrm{BF} \%$ in Indians. The difference in $\mathrm{BF} \%$ between the $4 \mathrm{C}$ model and densitometry in Indian men was significantly greater than that for Chinese men $(P<0.05)$. These mean differences in BF\% between the 4C model and the 2C models were not statistically significant between ethnic groups (for men) after correction for age, $f_{\text {water }}$ and $f_{\text {mineral }}$ differences among groups, using analysis of covariance with Bonferroni testing for multiple comparisons. Fig. 1 presents the $95 \%$ CI for the differences in $\mathrm{BF} \%$ between the $4 \mathrm{C}$ model and $2 \mathrm{C}$ models. For most groups, these differences in $\mathrm{BF} \%$ were significantly different from zero $(P<0.05)$, except among Malay men and women (hydrometry) and Chinese men (hydrometry and densitometry).

Table 4 shows the partial correlations between the

Table 3. Comparison of differences between percentage body fat derived from the four-compartment model (4C) and those derived from the two-compartment models, by ethnic and gender groups for Singaporean Chinese, Malay and Indian participants in the bodycomposition study*

(Mean values and standard deviations)

\begin{tabular}{|c|c|c|c|c|c|c|}
\hline & \multicolumn{2}{|c|}{ Chinese } & \multicolumn{2}{|c|}{ Malays } & \multicolumn{2}{|c|}{ Indians } \\
\hline & Mean & SD & Mean & SD & Mean & SD \\
\hline \multicolumn{7}{|l|}{ Females } \\
\hline Hydrometry & $-1 \cdot 0$ & $2 \cdot 3$ & 0.1 & 2.5 & -0.8 & $2 \cdot 4$ \\
\hline DXA & $2 \cdot 1$ & $2 \cdot 6$ & 2.5 & 2.5 & $2 \cdot 3$ & $2 \cdot 4$ \\
\hline Densitometry & 3.2 & $2 \cdot 1$ & 1.9 & $2 \cdot 6$ & $2 \cdot 7$ & $2 \cdot 6$ \\
\hline Males & & & & & & \\
\hline \multicolumn{7}{|l|}{ 4C minus: } \\
\hline Hydrometry & 0.3 & $2 \cdot 0$ & 0.0 & $2 \cdot 6$ & -1.4 & $2 \cdot 7$ \\
\hline DXA & $4 \cdot 2$ & $2 \cdot 4$ & 3.9 & $2 \cdot 4$ & $3 \cdot 2$ & 3.0 \\
\hline Densitometry & 0.5 & $2 \cdot 0$ & $1 \cdot 2$ & $3 \cdot 0$ & 2.5 & $2 \cdot 6$ \\
\hline
\end{tabular}

No significant statistical difference between ethnic groups using analysis of covariance (with Bonferroni test for multiple comparisons), with correction for differences in age, water fraction and mineral fraction between groups (for details, see pp. 492-493).

DXA, dual-energy X-ray absorptiometry.

${ }^{*}$ For details of subjects and procedures, see Table 1 and pp. 492-493. 
(a)

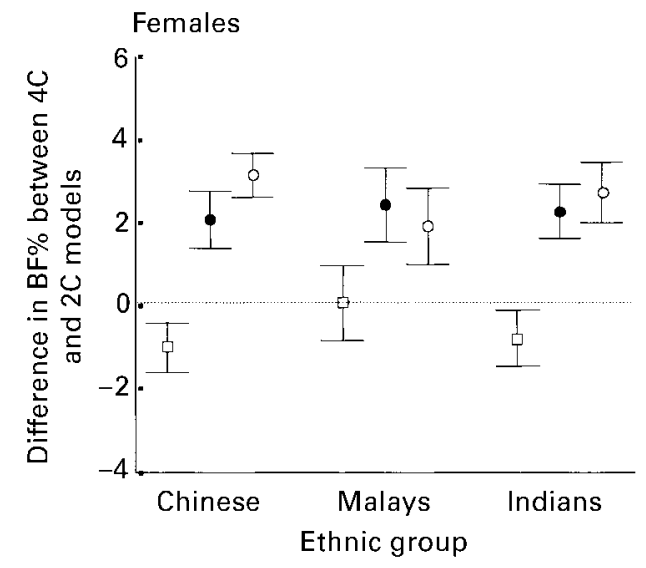

(b)

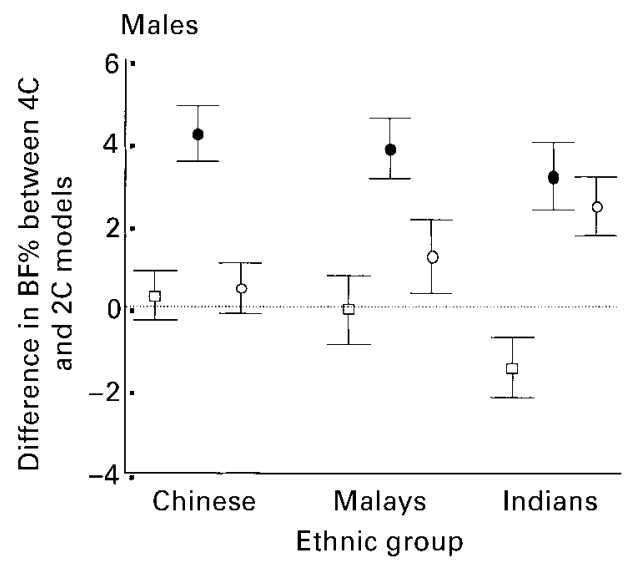

Fig. 1. Comparison of differences in body fat percentage (BF\%) obtained from the four-compartment (4C) model and from two-compartment (2C) models (hydrometry, $\square$; dual-energy X-ray absorptiometry, $\bullet$; densitometry, O). (a) female and (b) male Singaporean Chinese, Malay and Indian participants in the body-composition study. Points are means with $95 \% \mathrm{Cl}$ represented by vertical bars. For details of subjects and procedures, see Table 1 and p. 492.

differences in $\mathrm{BF} \%$ from the $4 \mathrm{C}$ model and the $2 \mathrm{C}$ models and $\mathrm{BF} \%$ from the $4 \mathrm{C}$ model (Fig. 2), $f_{\text {water }}, f_{\text {mineral }}$ and the density of FFM, with correction for age and ethnicity. The differences between $\mathrm{BF} \%$ from the $4 \mathrm{C}$ model and $\mathrm{BF} \%$ from both ${ }^{2} \mathrm{H}_{2} \mathrm{O}$ and densitometry were strongly correlated with the $f_{\text {water. }}$ However, the difference in BF\% between the $4 \mathrm{C}$ model and ${ }^{2} \mathrm{H}_{2} \mathrm{O}$ was positively correlated ( $r 0.99$ for both men and women), while the difference in $\mathrm{BF} \%$ between the 4C model and densitometry was negatively correlated (females $r-0.86$, males $r-0.89$; $P<0.05$ ).
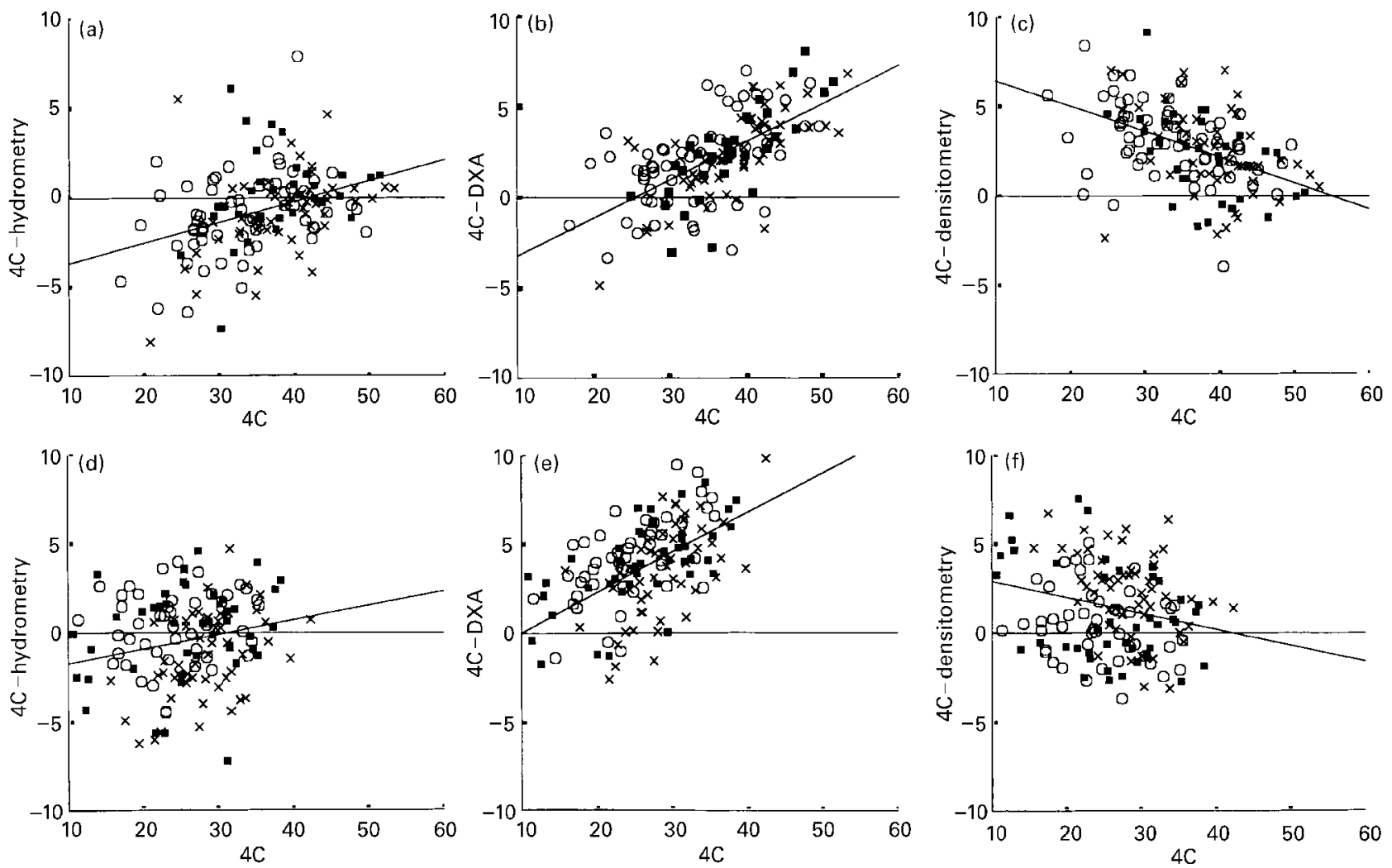

Fig. 2. Regression lines showing differences in body fat percentage (BF\%) between the four-compartment (4C) model and two-compartment models (hydrometry, dual-energy X-ray absorptiometry (DXA) and densitometry) $v$. BF\% from the 4C model in different Singaporean ethnic groups (Chinese, $O$; Malays, $\mathbf{\square}$; Indians, $x$ ) for (a-c) female and male (d-f) participants in the body-composition study. For details of subjects and procedures, see Table 1 and p. 492. 
Table 4. Correlations $(r) \dagger$ between the differences in percentage body fat BF\% from the four-compartment model (4C) and the twocompartment models and BF\% 4C water fraction $\left(f_{\text {water }}\right)$ mineral fraction $\left(f_{\text {mineral }}\right)$ and density $\left(D_{\mathrm{FFM}}\right)$ of fat-free mass (FFM) for Singaporean Chinese, Malay and Indian participants in the bodycomposition study $\ddagger$

\begin{tabular}{lrrlr}
\hline & BF\% 4C & $f_{\text {water }}$ & $f_{\text {mineral }}$ & $\mathrm{D}_{\mathrm{FFM}}$ \\
\hline Females & & & & \\
4C minus: & & & & \\
Hydrometry & $0.35^{*}$ & $0.99^{*}$ & $0.19^{\star}$ & $-0.85^{\star}$ \\
DXA & $0.62^{*}$ & $0.57^{*}$ & 0.15 & $-0.47^{*}$ \\
$\quad$ Densitometry & $-0.39^{*}$ & $-0.86^{*}$ & $0.31^{*}$ & $0.99^{*}$ \\
Males & & & & \\
4C minus: & & & & \\
Hydrometry & $0.33^{*}$ & $0.99^{*}$ & 0.02 & $-0.90^{*}$ \\
DXA & $0.56^{*}$ & $0.51^{*}$ & $0.18^{*}$ & $-0.38^{*}$ \\
Densitometry & $-0.33^{*}$ & $-0.89^{*}$ & $0.41^{*}$ & $0.99^{*}$ \\
\hline
\end{tabular}

DXA, dual-energy X-ray absorptiometry.

* $P<0.05$

$\dagger$ Pearson partial correlation coefficients with correction for age and ethnicity. ‡ For details of subjects and procedures, see Table 1 and p. 492.

The difference in BF\% between the $4 \mathrm{C}$ model and DXA was also significantly correlated with $f_{\text {water }}$ (females $r 0.57$, males $0.51, P<0.05$ ). The differences in $\mathrm{BF} \%$ between the $4 \mathrm{C}$ model and ${ }^{2} \mathrm{H}_{2} \mathrm{O}$, densitometry and DXA were also strongly correlated with the density of FFM, but they were the opposite of those of $f_{\text {water }}$. The $f_{\text {mineral }}$ was correlated positively with the differences in $\mathrm{BF} \%$ between the $4 \mathrm{C}$ model and ${ }^{2} \mathrm{H}_{2} \mathrm{O}$ and densitometry in women, and DXA and densitometry in men, but to a lesser extent than for $f_{\text {water }}$.

\section{Discussion}

The present study shows that the use of $2 \mathrm{C}$ models to determine BF\% in adult Singaporeans instead of 4C models leads to large individual errors in the $\mathrm{BF} \%$ measurement. On a group level, the best $2 \mathrm{C}$ model for $\mathrm{BF} \%$ measurement was found to be hydrometry.

The study samples were selected from the population sample of the National Health Survey conducted in 1998 (Ministry of Health, 1999), to ensure that there was adequate representation from each of the three ethnic groups (Chinese, Malays and Indians) for each gender group. As the purpose of the present study was to compare BF\% measurement using different methodologies, it was vital that there were enough subjects in the entire age and BMI range of the main sample of the survey rather than to have a truly random sample of the population. Nonetheless, the conclusions of this study are relevant for adult Chinese, Malays and Indians in Singapore.

All measurements were performed using the same instrumentation and by the same team of investigators using standardised protocols in order to avoid any systematic technical bias. A correction factor of 1.167 was applied to BMC measurements in this study using the Hologic $^{\circledR}$ absorptiometer to correct for measurements obtained using the Lunar ${ }^{\circledR}$ absorptiometer. This correction was necessary as the Baumgartner et al. (1991) formula used in the present study was developed using a Lunar ${ }^{\circledR}$ absorptiometer. The correction factor was obtained by making twenty repeated phantom measurements using each absorptiometer and also by making repeated sets of measurements for two subjects scanned using both types of absorptiometer over a period of 1 year. This factor is close to the factor of 1.154 found by Tothill et al. (1994). Body volume as measured by air displacement using the Bodpod $^{\circledR}$ and hydro-densitometry gave comparable results, as reported in the literature for young adults (Dempster \& Aitkens, 1995; McCrory et al. 1995; Nuñez et al. 1999). However, small differences have also been reported between air displacement and hydro-densitometry, with values from air displacement being both higher (Yee \& Kern, 1998) and lower (Collius et al. 1998; MillardStanford et al. 1998).

On a group level, the mean differences in $\mathrm{BF} \%$ between the $4 \mathrm{C}$ model and ${ }^{2} \mathrm{H}_{2} \mathrm{O}$ and densitometry were small, at $2.5 \%$ or less, while the mean difference in $\mathrm{BF} \%$ between the $4 \mathrm{C}$ model and DXA was higher, between $2.1 \%$ and $4.2 \%$. Generally, the BF\% obtained from hydrometry agreed most closely with that from the $4 \mathrm{C}$ model, with the smallest mean difference (Table 3 and Fig. 1). However, individual errors were much higher, owing partly to biological variation in the composition of the FFM (mainly in $f_{\text {water }}$ and to a lesser extent $f_{\text {mineral }}$ ) and partly to measurement errors inherent for each method. The maximum individual error was about $10 \%$ for all three methods.

The correlations of differences in $\mathrm{BF} \%$ between the $4 \mathrm{C}$ model and ${ }^{2} \mathrm{H}_{2} \mathrm{O}$ and densitometry with $\mathrm{BF} \%$ from the $4 \mathrm{C}$ model (Fig. 2) are partly contributed by the differences in $f_{\text {water }}$ and density of FFM between lean and obese subjects observed in this study. Leaner subjects tended to have lower $f_{\text {water }}$ and higher density of FFM than the assumed values of 0.735 and $1.100 \mathrm{~kg} / \mathrm{l}$ (data not shown) respectively, leading to overestimation of $\mathrm{BF} \%$ by hydrometry and underestimation of $\mathrm{BF} \%$ by densitometry. This increase in $f_{\text {water }}$ and decrease in density of FFM with increasing BF\% confirmed the theory discussed in the literature (Deurenberg et al. 1989b; Waki et al. 1991). No age influence on $f_{\text {water }}$ and density of FFM was observed in the subjects of the present study, even though this effect was reported in other studies (Deurenberg et al. 1989a; Bergsma-Kadijk et al. 1996) most probably owing likely due to the lack of sufficient subjects in the extreme agegroups $(<20$ years and $>65$ years) in the present study sample. Some researchers have conjectured that the water and BMC of the female body are more variable than those in males, and that $2 \mathrm{C}$ models would be less valid with higher individual error in females (Bunt et al. 1989; Vogel \& Friedl, 1992; Côté \& Adams, 1993). However, the present study does not support this hypothesis, as it can be seen from Tables 2 and 3 that in both males and females similar variability exists in the composition of FFM and biases in $\mathrm{BF} \%$ measurement for different $2 \mathrm{C}$ models.

The differences in $\mathrm{BF} \%$ from the $4 \mathrm{C}$ model and the three 2C models were mainly related to $f_{\text {water }}$, density of FFM and, to a lesser extent, the $f_{\text {mineral }}$, as can be seen in Table 4 . An $f_{\text {water }}$ smaller than the assumed 0.735 causes an overestimation of $\mathrm{BF} \%$ by hydrometry (Pullicino et al. 1990), while a higher density of FFM than the assumed $1.100 \mathrm{~kg} / \mathrm{l}$ would lead to underestimation of $\mathrm{BF} \%$ by 
densitometry (Fogelholm \& van Marken Lichtenbelt, 1997). In the present study, the $f_{\text {water }}$ values for the subgroups were very close to the assumed value, leading to small mean bias and error when estimating $\mathrm{BF} \%$ using hydrometry. On the other hand, the higher density of FFM in most groups resulted in systematic underestimation of $\mathrm{BF} \%$ by densitometry at the group level. DXA also systematically underestimated BF\% in all groups in the present study. The positive correlation of the bias from $\mathrm{BF} \%$ estimation by DXA with $f_{\text {water }}$ and $f_{\text {mineral }}$ and negative correlation with density of FFM showed that DXA has its limitations (Laskey et al. 1992; van Loan \& Mayclin, 1992) and is not entirely free of assumption of constant hydration (Roubenoff et al. 1993).

\section{Conclusion}

From the present study, it was found that in almost all groups there were significant differences between BF\% measured by the 4C model and that measured using hydrometry, DXA and densitometry. On a group level, there was systematic underestimation of BF\% by DXA and densitometry due mainly to violation of assumptions of constant hydration and density of FFM used in these 2C models. The difference in BF\% between the $4 \mathrm{C}$ model and ${ }^{2} \mathrm{H}_{2} \mathrm{O}$ approached zero for all groups. The differences in BF\% from the $4 \mathrm{C}$ model and ${ }^{2} \mathrm{H}_{2} \mathrm{O}$, densitometry and DXA between ethnic groups were mostly attributed to the differences in composition of FFM, mainly $f_{\text {water }}$ and partly to $f_{\text {mineral }}$. Similarly, the relationship between the differences in $\mathrm{BF} \%$ from the $4 \mathrm{C}$ model and ${ }^{2} \mathrm{H}_{2} \mathrm{O}$, and densitometry and DXA and the degree of body fatness could be partly explained by the increasing $f_{\text {water }}$ and decreasing density of FFM as BF\% increases. There was no observed age influence on the differences between $\mathrm{BF} \%$ measured by the $4 \mathrm{C}$ model and different $2 \mathrm{C}$ models.

There were considerable errors for all the $2 \mathrm{C}$ models due to individual differences in the $f_{\text {water }}$ and density of FFM from the assumptions made in these models. Thus, on an individual level, to obtain an accurate measure of $\mathrm{BF} \%$, a 4C model would be advisable. Certainly, if the hydration and density of FFM in specific population groups are known and used, hydrometry and densitometry could be used as measurements of $\mathrm{BF} \%$. However, as this approach is not always feasible for population studies, the choice of method would need to take into account the precision of the methodology and the agreement of the method with the reference $4 \mathrm{C}$ model. In these conditions, $\mathrm{BF} \%$ measurement using hydrometry is the method of choice when compared with densitometry and DXA. Additional advantages of hydrometry that make it suitable for use in field conditions are low respondent burden and no requirement for cumbersome instrumentation.

\section{Acknowledgements}

The authors wish to acknowledge their appreciation to: the National Medical Research Council in Singapore for funding the study; the subjects who took part in this study and cooperated fully throughout all measurements; Mr Frans JM Schouten (Wageningen Agricultural
University, The Netherlands) who analysed the plasma samples for ${ }^{2} \mathrm{H}$ and to Ms Violette Lin and Mr Eddy Chong for their assistance in performing the field measurements in Singapore; the Epidemiology and Disease Control Department (Ministry of Health) for providing the sample population and data from the National Health Survey 1998; the Department of Nutrition (Ministry of Health), for administrative and logistic support.

\section{References}

Aloia JF, Vaswani A, Ma R \& Flaster E (1997) Comparison of body composition in Black and White pre-menopausal women. Journal of Laboratory and Clinical Medicine 129, 294-299.

Baumgartner RN, Heymsfield SB, Lichtman SM, Wang J \& Pierson RN Jr (1991) Body composition in elderly people: effect of criterion estimates on predictive equations. American Journal of Clinical Nutrition 53, 1345-1353.

Bergsma-Kadijk JA, Baumeister B \& Deurenberg P (1996) Measurement of body fat in young and elderly women: comparison between a four-compartment model and widely used reference methods. British Journal of Nutrition 75, 649657.

Bland JM \& Altman DG (1986) Statistical methods for assessing agreement between two methods of clinical measurements. Lancet i, 307-310.

Brodie D, Moscrip V \& Hutcheon R (1998) Body composition measurement: a review of hydrodensitometry, anthropometry, and impedance methods. Nutrition 14, 296-310.

Bunt JC, Lohman TG \& Boileau RA (1989) Impact of total body water fluctuations on estimation of body fat from body density. Medicine and Science in Sports and Exercise 21, 96-100.

Collins MA, Millard-Stanford ML, Evans EM, Snow TK, Roskopf LB \& Cureton KJ (1998) Validation of air displacement plethysmography for estimating body fat in young adults. Medicine and Science in Sports and Exercise 30, (Suppl), 823a.

Côté KD \& Adams WC (1993) Effect of bone density on body composition estimates in young adult black and white women. Medicine and Science in Sports and Exercise 25, 290-296.

Dempster P \& Aitkens S (1995) A new air displacement method for the determination of human body composition. Medicine and Science in Sports and Exercise 27, 419-425.

Deurenberg P (1992) The assessment of body composition: use and misuse. Lausanne, Switzerland: Annual Report of the Nestlé Foundation 35-72.

Deurenberg P, Leenen R, van der Kooy K \& Hautvast JGAJ $(1989 b)$ In obese subjects the body fat percentage calculated with Siri's formula is an overestimation. European Journal of Clinical Nutrition 43, 569-575.

Deurenberg P, Weststrate JA \& van der Kooy K (1989a) Is an adaptation of Siri's formula for the calculation of body fat percentage from body density in the elderly necessary? European Journal of Clinical Nutrition 43, 559-568.

Deurenberg-Yap M, Schmidt G, van Staveren W \& Deurenberg P (2000) The paradox of low body mass index and high body fat percent in Singapore. International Journal of Obesity 24, 1011-1017.

Fogelholm M \& van Marken Lichtenbelt W (1997) Comparison of body composition methods: a literature review. European Journal of Clinical Nutrition 51, 495-503.

Forbes GB (1987) Human body composition, New York: Springer Verlag.

Gallagher D, Visser M, Sepúlveda D, Pierson RN, Harris T \& Heymsfield SB (1996) How useful is body mass index for 
comparison of body fatness across age, gender, and ethnic groups? American Journal of Epidemiology 143, 228-239.

Gordon CC, Chumlea WC \& Roche AF (1988) Stature, recumbent length and weight. In Arthropometric Standardization Reference Manual [Lohman TG, Roche AF \& Martorell R, editors]. Champaign, IL: Human Kinetics Books.

Gurrici S, Hartriyanti Y, Hautvast JGAJ \& Deurenberg P (1998) Relationship between body fat and body mass index: differences between Indonesians and Dutch Caucasians. European Journal of Clinical Nutrition 52, 779-783.

Heymsfield SB, Wang Z, Baumgartner RN \& Ross R (1997) Human body composition: advances in models and methods. Annual Review of Nutrition 17, 527-558.

Jebb SA \& Elia M (1993) Techniques for the measurement of body composition: a practical guide. International Journal of Obesity 17, 611-621.

Jiang ZM, Yang NF, Chou C, Liu Z, Sun T \& Chen Y, et al. (1991) Body composition in Chinese subjects: comparison with data from North America. World Journal of Surgery 15, 95102.

Laskey MA, Lyttle KD, Flaxman ME \& Barber RW (1992) The influence of tissue depth and composition on the performance of the Lunar dual-energy X-ray absorptiometer whole-body scanning mode. European Journal of Clinical Nutrition 46, 3945.

Lohman TG (1996) Dual energy X-ray absorptiometry. In Human Body Composition [AF Roche, SB Heymsfield and TG Lohman, editors]. Champaign, IL: Human Kinetics.

Lukaski HC (1987) Methods for the assessment of human body composition: traditional and new. American Journal of Clinical Nutrition 46, 537-556.

Lukaski HC \& Johnson PE (1985) A simple, inexpensive method of determining total body water using a tracer dose of $\mathrm{D}_{2} \mathrm{O}$ and infrared absorption of biological fluids. American Journal of Clinical Nutrition 41, 363-370.

McCrory MA, Gomez TD, Bernauer EM \& Molé PA (1995) Evaluation of a new air displacement plethysmograph for measuring human body composition. Medicine and Science in Sports and Exercise 27, 1686-1691.

Millard-Stanford M, Collins MA, Rosskopf LB, Snow TK \& Webb SA (1998) Air displacement plethysmography compared to multi-component models for estimating body composition in African American men. Medicine and Science in Sports and Exercise 30, Suppl., 822a.

Ministry of Health (1999) Report of the National Health Survey 1998 Singapore: Epidemiology and Disease Control Department.

Nuñez C, Kovera AJ, Pietrobelli A, Heshka S, Horlick M, Kehayais JJ, Wang Z \& Heymsfield SB (1999) Body composition in children and adults by air displacement plethysmography. European Journal of Clinical Nutrition 53, 382-387.

Ortiz O, Russell M, Daley TL, Baumgartner RN, Waki M, Lichtman S, Wang J, Pierson RN Jr \& Heymsfield SB (1992) Differences in skeletal muscle and bone mineral mass between black and white females and their relevance to estimate body composition. American Journal of Clinical Nutrition 55, 8-13.

Pace N \& Rathbun EN (1945) Studies on body composition: water and chemically combined nitrogen content in relation to fat content. Journal of Biological Chemistry 158, 685-691.

Pullicino E, Coward WA, Stubbs RJ \& Elia M (1990) Bedside and field methods for assessing body composition: comparison with the deuterium dilution technique. European Journal of Clinical Nutrition 44, 753-762.

Roubenoff R, Kehayia JJ, Dawson-Hughes B \& Heymsfield SB (1993) Use of dual-energy X-ray absorptiometry in bodycomposition studies: not yet a 'gold standard'. American Journal of Clinical Nutrition 58, 589-591.

Schoeller DA (1996) Hydrometry. In Human Body Composition [AF Roche, SB Heymsfield and TG Lohman, editors]. Champaign, IL: Human Kinetics.

Siri WE (1961) Body composition from fluid spaces and density, analysis of methods. In Techniques for measuring body composition, pp. 223-244 [J Brozek and A Henschel, editors]. Washington, DC: National Academy of Sciences.

Tothill P, Avenell A \& Reid DM (1994) Precision and accuracy of measurements of whole-body bone mineral: comparison between Hologic, Lunar and Norland dual energy X-ray absorptiometers. British Journal of Radiology 67, 1210-1217.

van Loan MD (1998) Estimates of fat-free mass (FFM) by densitometry, dual energy X-ray absorptiometry (DXA), and bioimpedance spectroscopy (BIS) in Caucasian and ChineseAmerican women. Applied Radiation and Isotopes 49, 751-752.

van Loan MD \& Mayclin PL (1992) Body composition assessment: dual-energy X-ray absorptiometry (DXA) compared to reference methods. European Journal of Clinical Nutrition 46, 125-130.

Visser M, Gallagher D, Deurenberg P, Wang J, Pierson RN Jr \& Heymsfield SB (1997) Density of fat-free body mass: relationship with race, age, and level of body fatness. American Journal of Physiology 272, E781-E787.

Vogel JA \& Friedl KE (1992) Body fat assessment in women. Sports Medicine 13, 245-269.

Waki M, Kral JG, Mazariegos M, Wang J, Pierson RN Jr \& Heymsfield SB (1991) Relative expansion of extracellular fluid in obese vs. non-obese women. American Journal of Physiology 261, E829-E834.

Wang ZM, Deurenberg P, Guo SS, Pietrobelli A, Wang J, Pierson RN Jr \& Heymsfield SB (1998) Six compartments body composition model: Inter-method comparisons of total body fat measurement. International Journal of Obesity 22, 329-337.

Wang ZM, Deurenberg P, Wang W, Pietrobelli A, Baumgartner RM \& Heymsfield SB (1999a) Hydration of fat free mass: new physiological modelling approach. American Journal of Physiology 276, E995-E1003.

Wang ZM, Deurenberg P, Wang W, Pietrobelli A, Baumgartner RM \& Heymsfield SB (1999b) Hydration of fatfree body mass: review and critique of a classic body composition constant. American Journal of Clinical Nutrition 69, 833-841.

Wang J, Thornton JC, Burastero S, Shen J, Tanenbaum S, Heymsfield SB \& Pierson RN Jr (1996) Comparison for BMI and body fat percent among Puerto Ricans, Blacks, Whites and Asians living in the New York City area. Obesity Research 4, 377-384.

Wang J, Thornton JC, Russell M, Burastero S, Heymsfield SB \& Pierson RN (1994) Asians have lower body mass index (BMI) but higher percent body fat than do Whites: comparisons of anthropometric measurements. American Journal of Clinical Nutrition 60, 23-28.

Yee A, Kern M, (1998) Validation of the BODPOD: Method for estimating percent body fat in an elderly population. Medicine and Science in Sports and Exercise 30, Suppl., 824a. 